\section{Akuter Gichtanfall}

VON H. S. FÜEßL

\begin{abstract}
Der 46-jährige übergewichtige Mann ruft Sie um sieben Uhr früh im Notdienst an, weil er seit einigen Stunden stärkste Schmerzen im rechten Großzehengrundgelenk hat, die ohne Verletzung mitten in der Nacht aufgetreten sind.
\end{abstract}

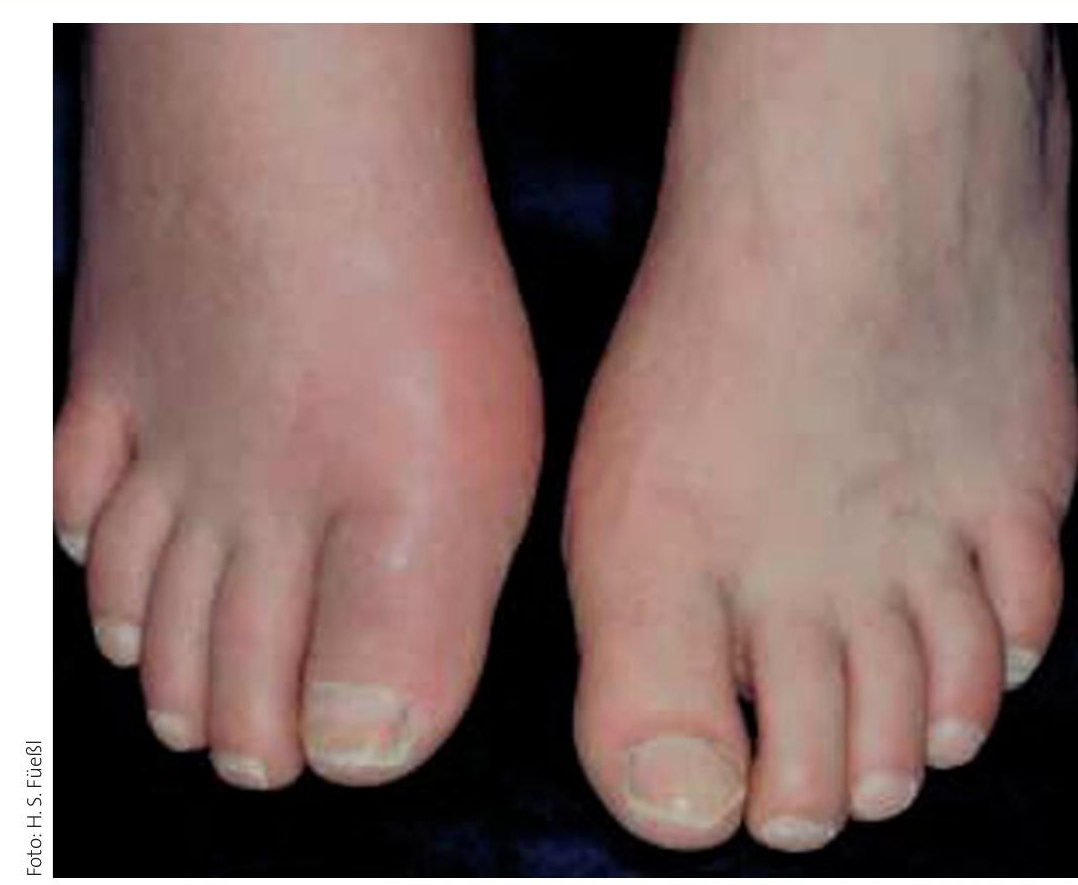

Colchicin, sodass dieses Medikament als eine Art von diagnostischer Test verwendet werden kann. 0,5 mg Colchicin oral jede Stunde oder $1 \mathrm{mg}$ alle zwei Stunden bis zu eine Höchstdosis von $8 \mathrm{mg} / \mathrm{Tag}$. Wichtigste Nebenwirkungen sind Durchfälle und Übelkeit. Alternativ NSAR wie Indometacin oder Diclofenac. Falls dagegen Kontraindikationen bestehen, Kortikosteroide systemisch oder intraartikulär.

Nach der Akuttherapie Dauertherapie mit Allopurinol und/ oder Benzbromaron mit Absenkung der Serum-Harnsäure auf unter $3 \mathrm{mg} / \mathrm{dl}$.

\section{Klinikeinweisung}

Ist meistens nicht erforderlich.

\section{Woran noch denken?}

- Lokales Trauma (im alkoholisierten Zustand!)

- Chondrokalzinose (Pseudogicht): kein Ansprechen auf Colchicin.

- Bakterielle Arthritis

- Arthrose im Reizzustand

- Psoriasis-Arthritis

(Befall im Strahl, „Wurstzehe“)

- Reiter-Syndrom

- Atypisch verlaufende rheumatoide Arthritis (meist Frauen)

\section{Anschrift des Verfassers:}

Prof. Dr. med. H. S. FüeßI, Internistische Abteilung, Bezirkskrankenhaus Haar, Ringstr. 33 A, Postfach 1111, D-85540 Haar, E-Mail: fueessl@krankenhaus-haar.de 